« Orientalism in Late Antiquity? The Oriental in Imperial and Christian Imagery $"$, in : J. Wiesehöfer, Ph. Huyse, éds., Erā̄n und Anērān. Studien zu den Beziehungen zwischen dem Sasanidenreich und der Mittelmeerwelt. Beiträge des Internationalen Colloquiums in Eutin, 8-9 Juni 2000. Franz Steiner Verlag, 2006, pp. 241-278. (Oriens et Occidens 13)

Rika Gyselen

\title{
OpenEdition
}

\section{Édition électronique}

URL : http://journals.openedition.org/abstractairanica/27112

DOI : $10.4000 /$ abstractairanica. 27112

ISSN : 1961-960X

Éditeur:

CNRS (UMR 7528 Mondes iraniens et indiens), Éditions de l'IFRI

\section{Édition imprimée}

Date de publication : 15 mai 2008

ISSN : 0240-8910

Référence électronique

Rika Gyselen, « « Orientalism in Late Antiquity? The Oriental in Imperial and Christian Imagery », in : J. Wiesehöfer, Ph. Huyse, éds., Ėrān und Anērān. Studien zu den Beziehungen zwischen dem Sasanidenreich und der Mittelmeerwelt. Beiträge des Internationalen Colloquiums in Eutin, 8-9 Juni 2000. Franz Steiner Verlag, 2006, pp. 241-278. (Oriens et Occidens 13)», Abstracta Iranica [En ligne], Volume 29 | 2008, document 129, mis en ligne le 15 septembre 2008, consulté le 26 septembre 2020. URL : http:// journals.openedition.org/abstractairanica/27112; DOI : https://doi.org/10.4000/abstractairanica. 27112

Ce document a été généré automatiquement le 26 septembre 2020. 
«Orientalism in Late Antiquity? The Oriental in Imperial and Christian Imagery ", in : J. Wiesehöfer, Ph. Huyse, éds., Ērān und Anērān. Studien $z u$ den Beziehungen zwischen dem Sasanidenreich und der Mittelmeerwelt. Beiträge des Internationalen Colloquiums in Eutin, 8-9 Juni 2000. Franz Steiner Verlag, 2006, pp. 241-278. (Oriens et Occidens 13)

Rika Gyselen

L'A. commente des aspects de l'orientalisme à Rome et à Byzance dans des scènes narratives comme les processions de porteurs de tribut qui dans l'imagerie chrétienne se retrouvent dans la " procession " des trois rois mages devant l'enfant Jésus. L'oriental y est caractérisé par le luxe vestimentaire et la richesse des cadeaux qu'il offre. Un autre topos dans l'iconographie romaine est l'oriental vaincu agenouillé. Ce motif trouve un écho sur les reliefs de Shapur I où sont représentés de la même façon les empereurs romains vaincus. 
INDEX

Thèmes : 3.2.3. Séleucides, Parthes et Sassanides

\section{AUTEURS}

RIKA GYSELEN

CNRS - Mondes iranien et indien - Paris 